\title{
The Inappropriateness of English for Specific Purposes (ESP) with Learner's Goals: A Need Analysis on Communication and Islamic Broadcasting Program
}

\author{
St. Hartina ${ }^{1}$ and Syahrir Syahrir ${ }^{2}$ \\ ${ }^{1}$ Institut Agama Islam Negeri Palopo, Palopo, Indonesia \\ ${ }^{2}$ Universitas Muhammadiyah Palopo, Palopo, Indonesia \\ sthartina@iainpalopo.ac.id
}

\section{ARTICLE HISTORY \\ Received : 2 May 2021 \\ Revised : 4 May 2021 \\ Accepted : 7 August 2021}

\section{KEYWORDS}

Inappropriateness

English for Specific Purposes (ESP)

Need Analysis

Communication

Islam

Islamic Broadcasting Program

\begin{abstract}
The course of English for Specific Purposes (ESP) is supposed to prepare students for the professional sector, yet the course at IAIN Palopo in Indonesi is designed in general English without any professional input or assessment of the learner's needs. This research is motivated by the Communication and Islamic Broadcasting program students' complaints of unsatisfaction with the course since it does not meet their needs. This research aims to examine the English needs of students studying in the communication and Islamic broadcasting program. The researchers used a mixed-methods strategy that incorporates both quantitative and qualitative research. The participants in this study were 60 undergraduates and 30 graduate students. Data was gathered through questionnaires and interviews. The data was then analyzed using the comprehensive concept of need analysis proposed by DudleyEvans \& St. John (1998). The results revealed that the majority of students learn English to help them advance in their careers. Their top priority in ESP is to improve their speaking skills, followed by listening, reading, and writing. Due to the repetitive learning method, inappropriate textbook, and short duration, according to the interview results, the students were also unsatisfied with the present ESP course.
\end{abstract}

\section{Introduction}

During the last two decades, the demand for English for Specific Purposes (ESP) has been a major priority. It has grown very rapidly since 1960 (Hutchinson \& Waters, 1987). The main reason why more people throughout the world, particularly in Asia, are interested in learning English is that it improves societal attitudes about language (Aliakbari \& Boghayeri, 2014). The growth of worldwide scientific, technological, social, and commercial activities increased the need for English for specific purposes. It was utilized in a variety of fields, including trade, technology, health, finance, and science research. Furthermore, the majority of job vacancies, as well as the rising number of international students, require not just specialized skills but also a strong command of the English language (Nimasari, 2018). As a result, scholars who are job seekers are expected to have a strong command of the English language to pursue their careers in the future (Asrifan et al., 2020). Educational institutions are now obligated to incorporate an ESP course in their curriculum (Boroujeni \& Fard, 2013) as a result of the demands.

Mazdayasna \& Tahririan (2008) studied the English needs of Iranian medical students. They discovered that the ESP course was ineffective since it did not meet the learners' needs. In another study in Iran, Bigdeli (2010) revealed inconsistencies between students' ESP needs and the actual
English material provided. In a similar example, Chostelidou (2010) sought to create an ESP syllabus for Greek tertiary education. He discovered that the learners' attitudes on using the target language for professional reasons differed. In addition, Kadek et al., (2016) recognized the critical need for English-speaking nurses in Bali. As a result, he decided to design an innovative ESP syllabus to meet the learners' expectations of English usage. Therefore, it was clear that the majority of ESP courses were designed without considering the learners' needs.

Although the teaching of ESP is nearly identical to the teaching of English for General Purposes, there are significant differences to be considered. The ESP course, according to Edwards (2000), is "something outside of the language through the means of the language." The role of ESP is supposed to be as an essential tool for learners to improve their English skills in preparation for their professional sector. Hutchinson \& Waters (1987) endorsed the same notion, stating that ESP should be focused on the learners' needs in their professional fields. Due to these factors, teachers found it difficult to develop different syllabuses. Teachers should examine the learning objectives for each subject to design a course that is both engaging for students and effective for their future careers.

In Indonesian universities, ESP is generally studied after general English. It is usually offered at the tertiary level of 
education. Khalik (2014) in his research at the University of 45 Makassar found that ESP are taught at Semester 3 after students have completed General English. Also Kusni, (2013) claimed that General English is basic language learning to be studied at lower level and continue to ESP which is more advanced, professional, and related to the

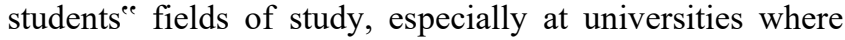
students are trained to perform on their future job. However, the degree of difficulty does not meet the needs of Indonesian students. The present ESP syllabus for nursing students is not yet completely practical in terms of topic setting and seems difficult to implement in the classroom (Kadek et al., 2016).Thus, the syllabus must be perfected in order to minimize inconsistencies between students' needs and the material being taught.

English for Specific Purposes is studied by all majors or study programs, including the Communication and Islamic Broadcasting program, in particular at Institut Agama Islam Negeri (IAIN) Palopo ESP is a required course in the third semester. On paper, the goal of the course is to educate nonEnglish students on how to understand and use the English language based on their academic background.

However, preliminary observation proved otherwise as an ESP lecturer in the Communication and Islamic Broadcasting program, the researcher discovered that the syllabus and course design were identical to those used in general English. Students have also complained to the researcher that this course does not meet their expectations. Following a review of the curriculum and interviews with the heads of the Communication and Islamic Broadcasting Program, it was discovered that no study focused on a needs analysis for undergraduate courses had been conducted. Without expert consultation or assessment of the learner's needs, ESP courses were implemented. Without going through a need analysis process, the course content is designed based on an English lecturer's personal experience. As a consequence, the English course content does not meet the learners' needs. Because they are unable to utilize English in a genuine setting, the students lack the desire to learn as a result of the differing expectations.

Unfortunately, this fact shows that the ESP program used so far is incompatible with the characteristic of the ESP course design. The current course does not accommodate the students' needs. One probable reason is that the ESP course does not cover this vital need, leaving a gap between the learners' needs and what the syllabus provides. There are inconsistencies between the learner's needs and the actual content they get in ESP courses. Therefore, updating the curriculum frequently is an option for ensuring that the course remains relevant to students' needs (Jackson, 2005). Previous studies indicated that when the syllabus is incompatible with the students' goal realization, teachers and lecturers alike must conduct a needs analysis to address the problem (Sumarsono et al., 2017).It is critical to do a need analysis to determine what students require. Hence, the importance of need analysis in the ESP curriculum should not be overlooked when investigating this topic.

Considering all of this, it appears that the present ESP curriculum and material should be updated. In other words, conducting a need analysis to determine the ESP learner needs would be beneficial. From the author's investigations, there is no study on need analysis for Communication and Islamic Broadcasting programs. Therefore, this study will provide preliminary information on the need for Languages for Communication and Islamic Broadcasting Programs. The present study aims to analyze the English needs and to explore the problems faced by students in learning ESP courses at Islamic Communication and Broadcasting Program.

The results will hopefully assist the teacher in determining the student's professional language skills. It is a critical step in offering well-designed educational materials to college students. It also serves as the basic information for developing curriculum content, teaching materials, and methods as part of the ESP course design framework, particularly for the Islamic Communication and Broadcasting Program.

\section{Literature Review}

\subsection{Need Analysis}

The process of gathering and assessing learner needs in order to design the curriculum content and goals is known as need analysis (Lin \& Wang, 2012). The goal of need analysis is to find out what the students need to know and what they do not know, as well as their existing abilities (Zamanian, Kashkouli, \& Seddighi, 2015). When developing an effective curriculum, the curriculum designer will determine the learning goals, language attitudes, and expectations of learners engaged in the course through this procedure (Bigdeli, 2010). The data obtained swill ensure that the courses are relevant and beneficial to the needs of the students. It will serve as a beginning point or guidance for the course and syllabus design, material selection, assessment, and even classroom activities (Gusti et al., 2014).

Hutchinson \& Waters (1987) divided needs into two categories: target and learning needs. Target needs are determined by considering necessities, lacks, and wants". In this context, "necessities" refer to what students must know. Meanwhile, "lacks" addresses students' current needs, while "wants" identifies learners' desires and what they find beneficial. It indicates that "wants" are connected to subjective needs, "necessities" are related to the necessary knowledge, and "lacks" are related to current knowledge."

Needs analysis, according to Dudley-evans (1998) includes target analysis, present situation analysis, and learning needs analysis. Target analysis is known as objective needs. Meanwhile, the present situation analysis is concerned with identifying the learners' lacks or deficiencies. 
Furthermore, the learning needs analysis is known as subjective needs. In other words, the target needs to examine the language needs where the participants are likely to use English. Meanwhile, the learning needs examined what the students expected from the course (Zamanian et al., 2015). The most essential aspect of need analysis is identifying the students' requirements, lacks, and desires, which may be viewed from a variety of viewpoints including students, teachers, and institutions (Otilia, 2015).

\subsection{English for Specific Purposes}

According to Hutchinson \& Waters (1987) English for Specific Purposes (ESP) is an approach for teaching English that focuses on the content and method needed by the students. This course's objective is to educate students on a set of abilities that they will need in their present employment or later in their professional careers. ESP is a teaching method that does not require the use of explicit words. The 'purpose' for which the learner is studying English is the most essential aspect of the language. It is designed to the needs of students from a wide range of disciplines (Warti, 2020). The term 'specific' in English for Specific Purpose refers to the uniqueness of learning objectives (Ekayati et al., 2020).

Adult learners are the target audience, whether it is a formal institution or a professional industry. Students attend English lessons in higher education not just because they want to learn English, but also because it is one of the mandatory subjects, regardless of whether or not they love it.

\subsection{The Role of Need Analysis in English for Specific Purposes}

In her study, Kadek (2016) looked at the needs of ESP for nursing students. The finding showed that most students have a limited vocabulary and are poor in speaking, listening, writing, and pronunciation. As a result of these findings, an innovative ESP syllabus for Indonesian nurses was created. It is critical to design an ESP course in order to enable students to communicate effectively and avoid any misconceptions when using English.

Chostelidou (2010) described the stage of a need analysis in creating ESP for Greek tertiary education. The first step is to determine the needs of a target group of learners and then design a course that meets those needs. The ESP for accounting courses, according to the findings, was designed not just for students but also for curriculum designers and ESP trainers.

For syllabus design, materials development, teaching, and assessment issues Sahraini (2020) argued that needs analysis is an essential element of ESP courses. In line with Otilia (2015), he stated that needs analysis is considered the cornerstone of English for Specific Purposes (ESP). It entailed analyzing the learners' communication needs as well as strategies for accomplishing specific teaching objectives.
Its goal is to gather information about the students and to define the target setting and atmosphere for the ESP study.

The University of Phayao conducted a need analysis in order to develop an appropriate ESP syllabus that meets the students' needs (Thepseenu, 2020) The results of this study are given to the curriculum designer to design a language course. Students will realize the value of a language course that is designed to meet their needs, and they will be more driven to study. The basic needs of students, the material focused on disciplines and professions, and the vocabulary focus on events are the characteristics of ESP . According to Dudley-evans (1998) today's concept of needs analysis has eight components that have been divided into five main categories, including 1. target situation and objective needs analysis (e.g., tasks and activities for which learners will use English); 2. linguistic, discourse, and genre analysis, i.e. an understanding of how language and abilities are employed in the target circumstances; 3. learners' goals, means, and subjective needs-factors that influence how individuals learn (e.g. prior learning experiences, reasons for attending the course, and expectations); 4. present situation analysis to determine learners' current skills and language usage; and 5. a means analysis (e.g. information about the environment where the course will occur).

It is important to undertake a need analysis as a first step in creating an ESP program so that it is in line with the actual needs of students (Torregrosa \& Sánchez-reyes, 2015). It can be done at the beginning of the course to determine the students' goals or at the end of the course for evaluation, and revision (Nation \& Macalister (2010). The results will assist the curriculum designer and the ESP teachers in identifying learner's needs.

The curriculum designer and ESP teacher will be aware of the student's perspective requirements, language skills, and language ability deficiencies. It is very important in designing the learning objectives, the selection of teaching materials, and appropriate learning techniques and resources. Needs assessment, course and syllabus design, content selection and production, teaching and learning process, and evaluation are the steps of ESP design (Hyland, 1999). These steps cannot be separated or overlapped since the ESP design would become chaotic.

\section{Method}

The research was conducted using both quantitative and qualitative methods. To collect primary data, a quantitative technique was utilized. Meanwhile, as secondary data, a qualitative method was taken to acquire a more relevant understanding. The participants were chosen at random from 60 students and 30 graduates of Communication and Islamic Broadcasting to answer the questionnaire. In addition, three students, two graduates, and three ESP teachers took part in the semi-structured interview as participants.

A questionnaire and a semi-structured interview were used to gather data. Mazdayasna's \& Tahririan's (2008) 
version of multiple-choice questions was utilized in the questionnaire. The following is an adaptation of the questionnaire from Dudley-evans (1998) comprehensive concept of need analysis:

Table 1. The concept of need analysis questions

\begin{tabular}{ll}
\hline \multicolumn{1}{c}{ Aspect } & The purpose of the question \\
\hline Target situations & To find out the purpose for \\
analysis & studying English \\
& To find out the priority of \\
& English skills \\
& To find out the necessities of \\
Objective need & learning each English skill \\
analysis & To find out the learners' \\
Subjective need & preferred learning methods of \\
analysis & each skill \\
\hline
\end{tabular}

The descriptive qualitative approach was used to examine the data collected from the questionnaires. The following methods were used to collect data via questionnaire: (1) determining the students' responses; (2) sorting the percentage of responses from the students; and (3) specifying the students' degree of needs.

On the other hand, the researcher also performed a semistructured interview to understand more about the difficulties students encounter when studying ESP and what they require from ESP class. The researcher asked five questions to five students and graduates individually. The questions were used to gather the data on the ESP course's learning techniques, ESP material sources, course length, and syllabus content. In addition, three ESP professors were asked two questions on the most important skill for students and the syllabus design. The data from the semi-structured interviews were qualitatively analyzed using Miles \& Huberman (1994) techniques for data collection, data reduction, and data displayed.

\section{Results}

The results were divided into four sections. It is used to investigate the learners' purpose of studying English, the priority order of English skills, the necessities of learning each English skill, and the learners' preferred learning activities.

\subsection{Learners' Purpose of Studying English}

The first questionnaire elements were designed to evaluate the purpose of the learners in studying English. As seen in Chart 1, there are $43 \%$ of participants believed that learning English helps to support their future career.

Chart 1. The learners' purpose for studying English

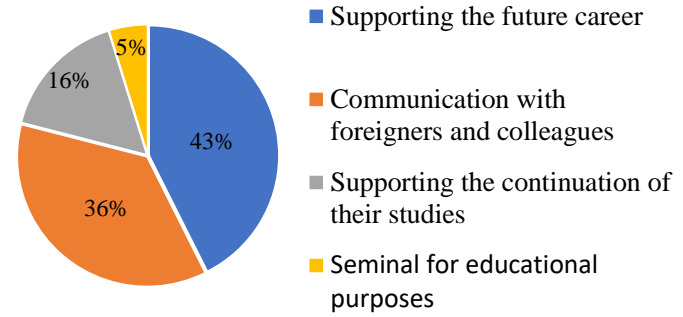

While 36 per cent said it was equally essential to communicate with foreigners and colleagues. Supporting the continuation of their studies received 16 percent of the vote, with 5 percent supporting the participation of seminars for educational purposes. The primary objective of students learning English is to support their future careers. This serves as a guide for developing a curriculum and preparing teaching materials that are relevant to the learners' future work.

Chart 2. The priority of English skill

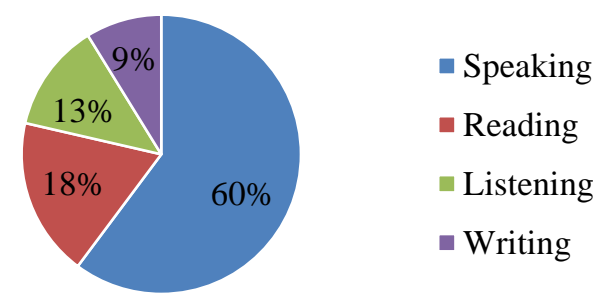

Chart 2 highlighted the priority of English skills that learners will require in their future jobs. The results revealed that speaking (60 percent) was the most important aspect of oral communication. Reading and comprehending texts came in second (18\%), followed by listening (13\%) and writing (9\%).

Because of their educational background in the field of communication and broadcasting, it was proven that speaking is the students' top priority in learning English. It required them to spend more time in the field and engage with others directly. Graduates are favored for jobs as preachers, journalists, public relations, television broadcasters, and guides. They are required to develop communication skills, particularly public speaking. Speech is the best introduction to learning other languages (Hussain, 2017). Learning a foreign language through speaking is a natural approach. Meanwhile, reading and comprehension of the text, as well as listening and writing are supporting skills.

\subsection{The Learners' Order of Priority of English Skills}

One of the most crucial aspects to assess is the necessity of learning each English skill. It was studied and classified into the following particular skills: reading, listening, speaking, and writing : 
Chart 3. Necessities of learning to read

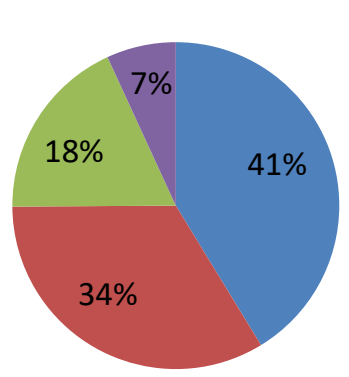

- Understanding the text in specialized textbooks

- Understanding the information in English magazines or newspapers. Understanding the information in English magazines or newspapers. - Guessing the meaning of words in English texts

The necessities of learners in learning to read were illustrated in chart 3 . The major priority with specialized textbooks $(42.1 \%)$ was to understand the text. Understanding information in English magazines or newspapers came in second $(34.3 \%)$, followed by understanding journal articles $(18.6 \%)$. Guessing the meaning of words in English texts is the last priority $(7 \%)$.

The result revealed that the students need to understand the information given in the textbook to improve their reading skills. According to Grabe \& Stoller, (2013), reading is the process of receiving and interpreting information encoded in language from a medium of print. It means that the textbook provided should be designed as an ESP book that is relevant to the student's academic background as the primary learning media. In addition to textbooks, reading comprehension may also be improved by other media, such as reading magazines, newspapers, and journal articles.

Chart 4. Necessities of learning listening

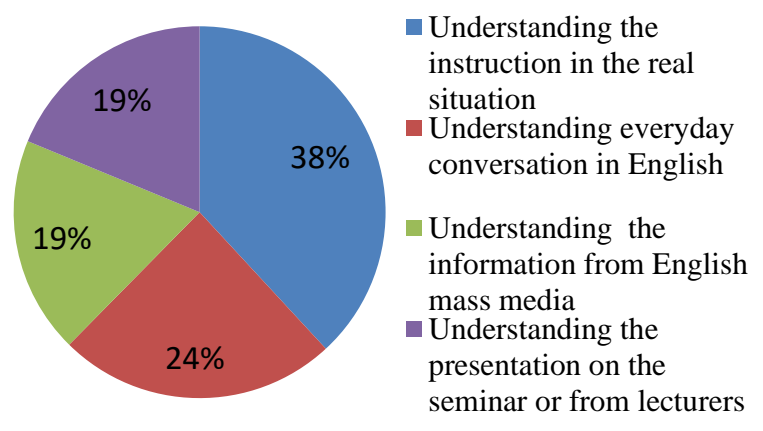

Regarding the necessities of listening, the learners believed that the primary importance is understanding the instruction in a real situation (38.2\%). Understanding everyday conversation in English $(24.3 \%)$ was also highly valued. Furthermore, understanding the information from English mass media (18.9\%) and understanding the presentation on the seminar or from lecturers $(18.8 \%)$ have almost the same priority.

The result revealed that listening learning should be designed in the form of teaching in context. Brown (2000) stated that authentic language and real-world tasks enable students to see the relevance of classroom activity to the students' long-term communicative goal. Conditioning the class in real situations according to the background, namely communication and broadcasting. For example, listening to a news anchor delivers the news to accelerate students to improve their listening skills.

Chart 5. Necessities of learning speaking

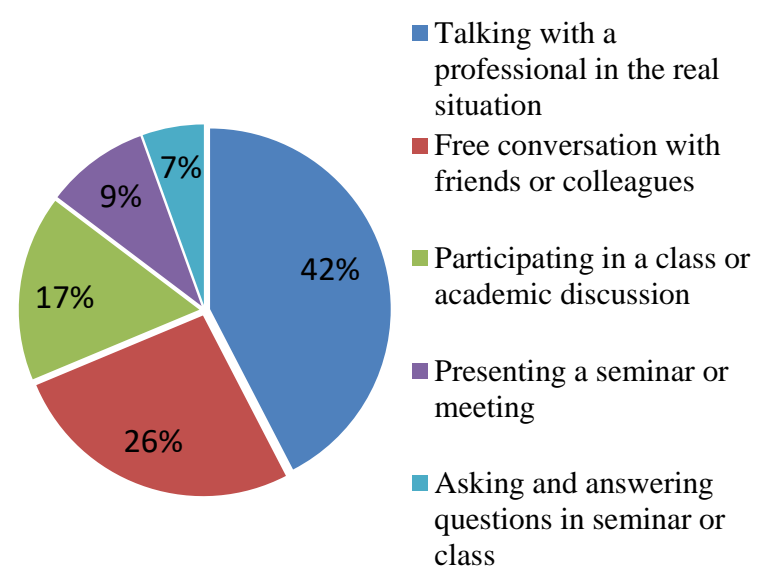

Chart 5 breaks down the necessities of learning speaking. It informed that talking with professionals in a real situation accumulated $42.4 \%$ as the major priority. Furthermore, $26.3 \%$ of the learners chose free conversation with friends or colleagues, participating in class or academic discussion (16.6\%), presenting a seminar or meeting $(9.2 \%)$, and asking and answering questions in seminar or class as the last.

Looking at the findings gathered from this section, it can be found that the learners recognized talking in real situations as the main purpose to learn speaking skills. It is supported by Richard (1990, p. 67) which stated that "the goals of teaching conversation are extremely diverse depending on the students, teacher, and overall context of the class." It means that the use of authentic language in a meaningful context will encourage the students speaking skills. It will support their careers in the future as the broadcaster.

Chart 6. Necessities of learning writing

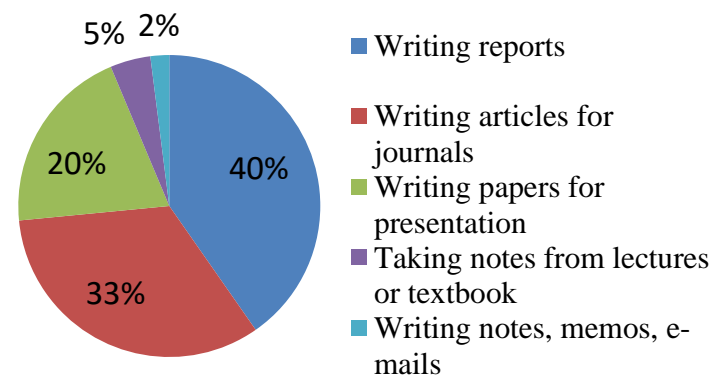


The last is assessing the learners' necessities of writing skills. The result in Chart 6 informed that $40.1 \%$ of the learners recognized writing reports as their most important need. Writing articles for journals is $33 \%$ agreement, writing papers for presentation $(20.1 \%)$, taking notes from lectures or textbooks $(4.3 \%)$, and writing notes, memos, and emails $(2.5 \%)$. The result indicated that writing activity should be mostly concerned with the final product of the writing report. Writing reports, article and paper are the kinds of display writing which allow students to convey the information on topics given. Brown (2000) argued that display writing exercises will help the students to succeed in further academic pursuits.

\subsection{The Necessities of Learning Each English Skill}

Learners' need is not only to focus on macro skills but also micro-skills. All activities in the class were intended to improve the learners' knowledge, skills, and competence in a micro skill. The result of learning activities preferred by the learners is presented in the following table:

Table 2. The preferred learning activities

\begin{tabular}{|c|c|c|}
\hline $\begin{array}{l}\text { English } \\
\text { skill }\end{array}$ & Learning Activity & Percentage \\
\hline \multirow{4}{*}{ Reading } & Reading to check information & 42.3 \\
\hline & $\begin{array}{l}\text { Answering questions about the } \\
\text { text }\end{array}$ & 33.2 \\
\hline & $\begin{array}{l}\text { Analyzing the meaning of new } \\
\text { vocabulary based on the context }\end{array}$ & 18.6 \\
\hline & $\begin{array}{l}\text { Reading aloud the text with } \\
\text { correct pronunciation and } \\
\text { intonation }\end{array}$ & 5.9 \\
\hline \multirow{4}{*}{ Listening } & Listen and follow instructions & 36.2 \\
\hline & Understanding main points & 30.4 \\
\hline & Identifying specific information & 23.7 \\
\hline & $\begin{array}{l}\text { Comprehending speakers with a } \\
\text { different accent }\end{array}$ & 9.7 \\
\hline \multirow{4}{*}{ Speaking } & $\begin{array}{l}\text { Practicing oral fluency are } \\
\text { practicing dialogue in front of the } \\
\text { class in pairs }\end{array}$ & 36.5 \\
\hline & Roleplay & 31.5 \\
\hline & Presentation & 24.6 \\
\hline & $\begin{array}{l}\text { Discussing certain topics or } \\
\text { certain problems }\end{array}$ & 7.7 \\
\hline Writing & Developing arguments & 37.6 \\
\hline
\end{tabular}

Summarize or rewrite the contents of the text

Compose random sentences and paragraphs

Practicing the use of appropriate vocabulary and grammar

Table 2 indicated that in teaching reading skills, $42.3 \%$ of participants chose reading to check information, and answering questions about the text $(33.2 \%)$ as the most appropriate learning activities. Besides that, analyzing the meaning of new vocabulary based on the context being read $(18.6 \%)$ and reading aloud the text with correct pronunciation and intonation $(5.9 \%)$ is the lowest chosen activity. The activities chosen by the students indicated that reading comprehension is a primarily efficient strategy. Development of reading comprehension ability can be applied by using skimming and scanning techniques to analyze and understand the contents of the text. After reading the text the students can answer the questions that are appropriate to the content's text. On the other hand, according to Brown (2000) reading aloud is not a very authentic language activity because while once a student is reading, others can easily lose attention. Hence, this activity is not recommended.

Regarding listening skills, the students considered that listening and following instructions $(36.2 \%)$ are the favored types of tasks, understanding main points $(30.4 \%$, identifying specific information $(23.7 \%)$, and understanding speakers with different accents $(9.7 \%)$. Students in Indonesia like listening and following instructions because it can be directly practiced. The sentences use in instruction are usually not too long so they are easy to understand by foreign speakers such as Indonesian students. Three listening activities were mostly chosen, namely listening and following instructions, understanding main points, and identifying specific information. These three activities the kinds of listening comprehension. Brown (2001) argued that the process of listening comprehension can be facilitating and interfering by using background information (schemata) and the cultural background of the students.

In speaking activities, the results of the need analysis indicated that practicing dialogue in front of the class in pairs with friends $(36.5 \%)$ was indicated as the most important task by the learners. On a similar line, role-playing received a significant percentage (31.5\%), Besides presentation gained $24.6 \%$ and discussing certain topics or certain problems is $7.7 \%$ votes. These results indicate that the two most activities chosen by students are practicing dialogue and role play. These two activities can be practiced in transactional and interpersonal dialogue that use authentic language in a meaningful context. Hartina (2020) argued that ne way to practice speaking skills is Learners should 
participate in the conversation, dialogue or role play. Meanwhile, presentation and discussion can be used as additional activities.

Finally, the results on writing skills inform the learners choose the process of written discourse such as "developing arguments" (37.6\%), summarize or rewrite the contents of the text (32.4\%), Compose random sentences and paragraphs $(23 \%)$, and practicing the use of appropriate vocabulary and grammar $(7 \%)$. The activity both developing arguments and summarize the text are the most chosen ones. Both of them are the complex process which started by putting the ideas down on paper to transform into words, sharpen the main ideas, give them structure and coherent organization. Even it is a complex process but it gives the chance to students to think as they write. Meanwhile, compose random sentences and practicing the use of appropriate vocabulary can be used as supporting activities. All writing practices are needed to produce a well-written text.

\subsection{The Results of the Interview}

To complete the data from the questionnaire, the interview was conducted to obtain the learning strategies in the ESP course, ESP material sources, course length, and syllabus content

The first question explored the students' point of view of learning strategies applied in the recent ESP course.

"The lectures explain the grammar rules and ask the students to memorize the vocabulary and grammar rules. Sometimes, we translate the text. It is monotonous and makes us boring."

Excerpt 1

"We were always asked to answer questions from reading or translating texts, only occasionally to practice dialogue."

Excerpt 2

The student's response above indicated that the learning methods in recent ESP are monotonous because they focus more on grammar rules, memorizing vocabulary, and translating. There is no real communication in the class that makes them be passive learners. Lack of variety in a lesson or limited exercise types will induce boredom to the learners. It needs to repeat things to learn them but frequent repetition creates boredom(Hutchinson \& Waters, 1987). Thus, the teachers need to increase the variety of learning methods and exercise types.

Responding to the question of dissatisfaction with the learning strategies used by ESP now, the researchers gave feedback about the strategies they wanted. Following are the responses from students:

"I want the learning method to be varied, not just reading and translating. We also want real learning such as being a presenter or interviewing in the field. It's not just learning in the classroom."
"I like if the learning is more direct practice, for example, role-play, investigation and then making a report"

Excerpt 4

The statement above indicated that students wanted a variety of learning methods. Variety is a vital element in keeping the learners' minds alert and focused on the task at hand (Hutchinson \& Waters, 1987). Variety can be achieved in a number of ways such as a variety of mediums, classroom organizations, learners' roles, exercise, topic, and skill. Teachers can choose these variations according to the learning objectives.

The second question asked about the improvement after studying ESP course, the graduates generally conveyed that their skills improved "very little".

\begin{abstract}
"I have very little improvement in English. To speak I am still very stiff. My vocabulary is also still limited to basic vocabulary."
\end{abstract}

Excerpt 5

"Very little, I think nothing special in studying ESP because the material is just the same in general English. I hope the English material is related to our major. It must encourage us to practice more especially in speaking, not just focus in reading the text."

Excerpt 6

The statement above shows that after studying ESP, students feel that there is no significant improvement. Lack of vocabulary mastery is one of the causes. They did not find anything special in the ESP course and felt that ESP was the same as general English. It showed that as the English users, the students hope that the English material being taught is not only general but is directed at the needs of English when they have graduated and entered the world of work.

Regarding the source of learning material, the student responded to the question as followed:

"We used textbook given by the lecturer but the textbook is not ESP book. I prefer to use online learning media such as youtube or E-book. The lecturer also can take the material from magazine or newspaper to use in the class."

Excerpt 7

The students' statement above suggested the textbooks used should be arranged according to their majors. To support the textbook as the main media, the online learning media from the internet was more interesting to use. Besides, taking references and related magazines or newspapers was also recommended to enrich their insight.

The third question identified the length of the ESP course. The graduate answered the questions as followed:

"I only study English for one semester, I hope English is taught for two semesters. So, one semester for General English, another semester for ESP."

Excerpt 8 
From the responses above, it can be concluded that learning English for one semester is not enough. Students need more time to explore ESP starting with General English first.

Apart from the learners and graduates, interviews were also conducted with ESP teachers. The respond of about the ESP course as followed:

"For this department, the skill needed is speaking because they are related to the social environment, but writing is also needed to write reports. I hope there will be regular evaluations on the syllabus and curriculum to keep it in line with student needs."

Excerpt 9

The comment of the ESP teacher described that the skill most required by learners was speaking skills since they had to engage in social communication and broadcasting such as preachers, journalists, public relations, television broadcasters, and event guides. Moreover, they had to write papers for broadcasting or publication. Thus, the learners could also be given the chance to practice their writing skills. The ESP teacher also hoped the cooperation of the head of a department to conduct regular evaluations of the curriculum and syllabus used by each ESP teacher. It is intended that the syllabus and teaching materials used in each class were similar so that all students got the same input. In developing a need-based syllabus, curriculum developers were expected to make more practice in macro and micro level skills.

\section{Discussion}

Because each learner or study group will have distinct needs, need analysis is extremely important in the ESP course. A learner's needs this year differ from those of learners in the same department three years ago, as they did two years later. It needs to analyze the target situations both in the short term (situations in which English is used for academic purposes and/or while the learner is still in study) and the long term (situations in which the use of English is used at work).

The findings of this need analysis give information on ESP needed in the communication and broadcasting program. In the long term, it has shown that students' objective in learning English is to continue their future professions. According to Warti (2020), the learning goals were emphasized on the specific English knowledge that the students will apply in their employment. Preachers, journalists, public relations, television broadcasters, and event guides are among the top jobs for the graduates of Communication and Islamic Broadcasting. They are required to develop communication techniques, especially public speaking. The aims of students in learning English, which place a high priority on speaking abilities, are consistent with earlier studies. Thepseenu (2020) in her research found that speaking is the most favored language skill and topic in ESP for Engineering. Boroujeni \& Fard (2013) also found that among the four abilities, speaking is the one that is taught and learned the fastest. Speech is the best introduction to other language learning skills and it's an opportunity given for the practical usage of a foreign language. It implies that in designing ESP class for Communication and Islamic Broadcasting, Overall skills, on the other hand, are required in both school and job situations.

The results showed that students require ESP for reading references, textbooks, and foreign journals for short-term academic objectives. Besides, the students can write abstracts for thesis purposes and writing short articles. Thus, the course content is required for both professional and academic objectives.

The following research findings detailed each skill's favorite learning activities. Overall pupils desired an active classroom environment where they are the center of activities and the teacher works as a facilitator and guide. As far as favorite learning activities go, pair and group work are the most popular. This finding Vongvilay et al.'s (2020) assertion, saying that group work would minimize the teacher talking and encourage students to speak. However, before students can speak, the students need to master listening skills first to obtain new vocabulary and how to pronounce a word (Nursafira, 2020).

Practicing dialogue and role play being the favorite activities which can be practiced through job interview dialogue, asking for salary raise, radio announcer, news anchor etc. Also discussing the trending issues, playing and mini-projects are some of the additional things that can be done as an out-of-door class. The students hope to gain greater experience to practicing English and engaging in teamwork by having outside classes (Nimasari, 2018). The teacher also can employed various types of activities such as watching videos on YouTube, online advertisements, English songs, and games to avoid students from boredom (Nurkhamidah et al., 2021).

The integrated teaching technique can then be used in classroom activities to engage the students' interests. This study showed that traditional approaches such as memorizing vocabulary, grammar, and translation do not inspire pupils to improve their communication abilities. Students merely remember phrase patterns and do not practice them in real-life situations. Vongvilay et al. (2020) stated that classical methods are unable to increase students' communication. Learning a language becomes rigid when vocabulary lists and grammatical rules are memorized without actual practice. Thus, employing a range of learning approaches is essential. The matter may be provided through a variety of mediums, classroom structure, learner roles, exercises, topics, and skills. Using the learning media is also a must. According to Astuti \& Nurhayati (2020) students prefer to find learning media on their own. In this case, they supported their learning through technology such as YouTube, music, and learning websites. 
The inappropriateness of ESP design with the learner goals suggested that the curriculum and syllabus revisions are required. When the current scenario does not satisfy the "identified needs" of the target learner, a modification of the ESP curriculum must be required (Long, 2010). In line with Richards (2001), saying that the introduction of the needbased syllabus as part of the process of curriculum renewal is highly recommended. Regular curricular changes may be quite beneficial in ensuring that courses remain relevant to students' requirements. Students will be able to practice receptive and productive abilities by using the new ESP syllabus design. As a consequence, the need-based syllabus documents represent their needs in terms of macro and micro-skills by selecting and assessing "authentic materials." As a result, newly developed courses should address their prior learning experiences, language proficiency level, and the challenges they face.

According to the researcher's point of view, ESP has the following characteristics: (1) It should be flexible and adaptable to the students' need; (2) It should be adjusted to the students" learning needs (allowing students to study their specialization more effectively) and also the students' target needs (allowing learners to function the language effectively in target situations); (3)It is not only presenting language items, skills and strategies but also the doing activities through which the language and content are learned.

In offering ESP courses in Indonesia, it is more effective and efficient to introduce a particular English diagnostic test or placement test for the new students of universities. The diagnostic test's purpose is to determine a student's level of English proficiency (basic, intermediate, or advanced). Those in basic level should not be allowed to take ESP classes, but should take EGP in one semester if available. If possible, students should take Introductory ESP subject (ESP subject designed as a transition subject from general English to advanced ESP subject) or advanced ESP subject after passing EGP.

Based on the result of need analysis, the researchers formulated the syllabus for Communication and Islamic Broadcasting which can be seen in the appendix (Table 3). Course developers can use the outcomes of this study to create an ESP course for the Communication and Islamic Broadcasting Program in the following academic year. Content descriptions and particular language skills can be used to guide the selection of acceptable techniques and subjects. It can also be used as a starting point for creating a coursebook or supplementary materials for students in this circumstance.

\section{Conclusion}

The research results highlighted that there is a gap between what learners believe to be their needs and what is covered in an ESP course since it is conducted without evaluating students' learning needs. Because of the monotonous learning method, inappropriate textbooks, and the short duration of the course, students were unsatisfied with the present ESP course. The need analysis showed that the student's motivation for studying English is to support their future career. Speaking was the most important English skill, followed by listening, reading, and writing. The aim of studying each English skill can be utilized to revise and improve the curriculum and ESP syllabus based on the needs of the students. These results most likely assist the teachers in determining the student's professional language skills. It serves as the basic information for developing curriculum content, teaching materials, and teaching methods for ESP, particularly for the Islamic Communication and Broadcasting Program. The most essential aspect of designing a syllabus and developing teaching materials is to consider the needs of the teacher as a facilitator as well as the needs of the students as user.

\section{References}

Aliakbari, M., \& Boghayeri, M. (2014). International Conference on Current Trends in ELT A Needs Analysis Approach to ESP Design in Iranian Context. Procedia - Social and Behavioral Sciences, 98, 175181. https://doi.org/10.1016/j.sbspro.2014.03.404

Asrifan, A., Vargheese, K. J., Syamsu, T., \& Amir, M. (2020). ESP Course Design: The need Analysis on Tourism Department in Indonesian Vocational High Schools. 3(2), 69-77.

Astuti, D., \& Nurhayati, W. (2020). Basic Need Analysis in Practical English Grammar : An Effort on Creating and Empowering Autonomy Learners. Indonesian Journal of English Language Teaching and Applied Lingusitics (IJELTAL), 4(2), 381-393.

Bigdeli, S. (2010). Syllabus revision : a needs analysis Study. 9,

https://doi.org/10.1016/j.sbspro.2010.12.325

Boroujeni, S. A., \& Fard, F. M. (2013). A Needs Analysis of English for Specific Purposes (ESP) Course For Adoption Of Communicative Language Teaching:(A Case of Iranian First-Year Students of Educational Administration). International Journal of Humanities and Social Science Invention, 2(6), 35-44.

Brown, H. D. (2000). Douglas. Teaching by Principles An Interactive Approach to Language Pedagogy by Brown H. (z-lib.org).pdf (p. 249).

Chostelidou, D. (2010). A needs analysis approach to ESP syllabus design in Greek tertiary education: a descriptive account of students' needs. Procedia Social and Behavioral Sciences, 2(2), 4507-4512. https://doi.org/10.1016/j.sbspro.2010.03.721

Dudley-evans, T. (1998). An Overview of ESP in the 1990s. The Japan Conference on English for Specific Purposes Proceedings.

Edwards, N. (2000). Language for business: effective needs assessment, syllabus design and materials preparation in a practical ESP case study. English for Specific Purposes, 19(3), 291-296. 
Ekayati, R., Manurung, I. D., \& Yenni, E. (2020). Need Analysis of ESP for Non-English Study Program. 4(2), 322-332. https://doi.org/10.30743/ll.v4i2.3152

Grabe, W., \& Stoller, F. L. (2013). Teaching and researching reading, second edition. In Teaching and Researching Reading, Second Edition. https://doi.org/10.4324/9781315833743

Gusti, A., Kristen, U., \& Wacana, S. (2014). The Role of Needs Analysis in English for Specific Purposes. January 1999. https://doi.org/10.15639/teflinjournal.v10i1/31-47

Hartina, S. . (2020). Talking Sticks as a Technique to Stimulate the Students' Speaking Performance. IDEAS: Journal on English Language Teaching and Learning, Linguistics and Literature, 8(1), 116-125. https://doi.org/10.24256/ideas.v8i1.1317

Hussain, S. (2017). Teaching Speaking Skills in Communication Classroom. International Journal of Media, Journalism and Mass Communications, 3(3). https://doi.org/10.20431/2454-9479.0303003

Hutchinson, T., \& Waters, A. (1987). English for Specific Purposes. In English for Specific Purposes. https://doi.org/10.1017/cbo9780511733031

Hyland, K. (1999). Developments in English for specific purposes: a multi-disciplinary approach; Tony Dudley-Evans and Maggie-Jo St John. 19, 297-300. https://doi.org/10.1016/s0889-4906(99)00026-5

Jackson, J. (2005). E NGLISH FOR An inter-university, cross-disciplinary analysis of business education: Perceptions of business faculty in Hong Kong. 24, 293-306. https://doi.org/10.1016/j.esp.2004.02.004

Kadek, N., Susandi, A., Luh, N., Krishnawati, P., Tinggi, S., Kesehatan, I., Inggris, J. S., \& Udayana, U. (2016). Needs Analysis : ESP Syllabus Design for Indonesian EFL. 130-140.

Khalik, L. A. (2014). ESP Needs Analysis Based Syllabus of Economics Faculty Students,University "45" Makassar. The Second International Conference on Education and Language (2nd ICEL) Bandar Lampung, 116.

Kusni, D. (2013). Reformulating English for Specific Purposes (ESP) in Indonesia: Current Issues And Future Prospects. SELT 2013 Proceeding, 36-48.

Lin, W. S., \& Wang, C. H. (2012). Antecedences to continued intentions of adopting e-learning system in blended learning instruction: A contingency framework based on models of information system success and task-technology fit. Computers and Education, 58(1), 88-99. https://doi.org/10.1016/j.compedu.2011.07.008

Long, M. H. (2010). Methodological issues in learner needs analysis. Second Language Needs Analysis, 19-76. https://doi.org/10.1017/cbo9780511667299.002

Miles, M. B., \& Huberman, A. M. (1994). Qualitative data analysis: An expanded sourcebook. sage.

Mazdayasna, G., \& Tahririan, M. H. (2008). Developing a profile of the ESP needs of Iranian students : The case of students of nursing and midwifery. Journal of English for Academic Purposes, 7(4), 277-289. https://doi.org/10.1016/j.jeap.2008.10.008

Nimasari, E. P. (2018). The Asian EFL Journal. Asian EFL Journal, 20(4), 261.

Nurkhamidah, N. (2021). University Students' Perspective on Material and Activities in English Listening Class During Pandemic. Elsya: Journal of English Language Studies, 3(2), 94-105.

Nursafira, M. S. (2020). TED Talks in EFL Context: An Alternative Way for Teaching and Improving Student's Speaking Skills. ELSYA: Journal of English Language Studies, 2(2), 43-47.

Otilia, S. M. (2015). Defining needs analysis in English for specific purposes (ESP). Needs Analysis in English for Specific Purposes, II(1), 54-55. https://doi.org/10.4324/9781315671390-8

Richards, J. C. (2001). Curriculum Development in Language Teaching. Cambridge University Press. https://doi.org/10.1017/CBO9780511667220

Sahraini. (2020). Developing English Material for Early Childhood Education Students at the Faculty of Education and Teacher Training in Islamic Higher Education, Indonesia. Asian EFL Journal, 27(4). https://www.asian-efl-journal.com/tag/volume-27issue-4-1-october-2020/

Sumarsono, D., Bagis, A. K., \& Arrafii, M. A. (2017). Students' Needs to Develop English Writing Materials. Lingua Cultura, 11(2), 67. https://doi.org/10.21512/lc.v11i2.1504

Thepseenu, B. (2020). Needs Analysis for ESP Course Development: Thai Civil Engineering Students ', Perspectives. 6(3), 433-442. https://doi.org/10.20448/journal.522.2020.63.433.442

Torregrosa, G., \& Sánchez-reyes, S. (2015). Target situation as a key element for ESP ( Law Enforcement) syllabus design. Procedia - Social and Behavioral Sciences, 173, $143-148$ https://doi.org/10.1016/j.sbspro.2015.02.044

Vongvilay, P., Kartika, D., \& Laila, M. (2020). Need Analysis of English Material for Vocational School of Health: A Case Study at One School at Karanganyar. Ethical Lingua: Journal of Language Teaching and Literature, 7(2), 360-368.

Warti, F. W. (2020). ESP Students' Needs Analysis Based on the Learning -Centred Approached. Wanastra: Jurnal Bahasa dan Sastra, 12(2), 164-170.

Zamanian, M., Kashkouli, S. M., \& Seddighi, S. (2015). Book review: designing language and teaching curriculum: Based on Nation and Macalister's (2010). International Journal of Educational Investigations, 2(2), 147-161. 


\section{Appendix}

Table 3. St. Hartina \& Syahrir's ESP Syllabus for Communication and Islamic Broadcasting Program

\begin{tabular}{|c|c|c|c|}
\hline Meeting & Topic & Learning Activities & Teaching Method \\
\hline 1 & $\begin{array}{l}\text { An introduction to English for } \\
\text { communication and broadcasting }\end{array}$ & $\begin{array}{l}\text { Introducing to English for communication } \\
\text { and broadcasting }\end{array}$ & Lecture \\
\hline 2 & Getting to know you & $\begin{array}{l}\text { Asking for and giving personal } \\
\text { information; } \\
\text { Introducing people }\end{array}$ & Pair work \\
\hline 3 & Mass Communication & $\begin{array}{l}\text { Talking about television program; } \\
\text { Retelling the favorite television program }\end{array}$ & $\begin{array}{l}\text { Communicative Language } \\
\text { Teaching (Retelling) }\end{array}$ \\
\hline 4 & Digital Media & Discussion experience in digital media & Group Discussion \\
\hline 5 & Public Opinion & $\begin{array}{l}\text { Asking for confirmation and clarification; } \\
\text { Identifying personal opinion }\end{array}$ & $\begin{array}{l}\text { Communicative Language } \\
\text { Teaching (Pair work) }\end{array}$ \\
\hline 6 & Radio and TV Broadcasting & $\begin{array}{l}\text { Making a podcast to practice as a } \\
\text { broadcaster }\end{array}$ & $\begin{array}{l}\text { Project-Based Approach } \\
\text { Role Play }\end{array}$ \\
\hline 7 & Promotion and advertising & Promoting a product or event & Project-Based Approach \\
\hline 8 & MID TEST & & \\
\hline 9 & $\begin{array}{llll}\begin{array}{l}\text { Reporting } \\
\text { Techniques }\end{array} & \text { and } & \text { News } & \text { Writing } \\
\end{array}$ & $\begin{array}{l}\text { Reading and understanding a magazine } \\
\text { article } \\
\text { Writing an opinion / description essay }\end{array}$ & $\begin{array}{l}\text { Intensive reading and } \\
\text { writing }\end{array}$ \\
\hline 10 & Lobby, presentation and negotiation & $\begin{array}{l}\text { Role play a meeting to negotiate solution } \\
\text { Using phrases to interrupt and prevent } \\
\text { interruption }\end{array}$ & $\begin{array}{l}\text { Role Play } \\
\text { Pair work }\end{array}$ \\
\hline 11 & Public Speaking & $\begin{array}{l}\text { Keeping the audience attention by using set } \\
\text { phrases }\end{array}$ & $\begin{array}{l}\text { Presentation, Practice and } \\
\text { Production }\end{array}$ \\
\hline 12 & Radio and TV reporting techniques & Reporting the news (new reporting) & Role play \\
\hline 13 & Radio and TV Talk show & $\begin{array}{l}\text { Role play an interview to defend one ideas } \\
\text { Debating a point of view }\end{array}$ & $\begin{array}{l}\text { Group work } \\
\text { Role Play }\end{array}$ \\
\hline 14 & Public Relation & $\begin{array}{l}\text { Using phrases to interrupt and prevent } \\
\text { interruption } \\
\text { Asking for and giving } \\
\text { information/direction }\end{array}$ & $\begin{array}{l}\text { Group work } \\
\text { Role Play }\end{array}$ \\
\hline 15 & News Anchor and Reporting & $\begin{array}{l}\text { Making a podcast to practice as the news } \\
\text { anchor }\end{array}$ & $\begin{array}{l}\text { Project Based Approach } \\
\text { Role-Play }\end{array}$ \\
\hline 16 & FINAL TEST & & \\
\hline
\end{tabular}

